\title{
RETROBULBAR NEURITIS IN CASES OF SEROUS MENINGITIS
}

\author{
BY \\ Professor Dr. Elena Puscariu \\ DIRECTOR OF THE OPHTHALMOLOGICAL CLINICS, JASSY, ROUMANIA
}

THE aetiology of retrobulbar neuritis, more than that of any other affection of the optic nerve, is frequently obscure. In the statistics of Herzog, for instance, we find among his 75 cases of retrobulbar neuritis 16 of unknown causation; in that of Scheerer Richard, 20 from 203.

In this respect the statistics show a great concordance, which does not subsist however, when we consider the multiple sclerosis, or the affections of the sinuses, which are thought, next to nicotinealcoholic intoxications, to be the most frequent causes of retrobulbar neuritis. From the 75 cases of Herzog one finds 47 with sinus infections. Only 13 of these showed serious troubles of the optic nerve, the rest had only a widening of the blind spot (sign of van der Hoeve). According to Herzog the sinuses had an influence in 2.6 per cent. of his cases. Multiple sclerosis, hysteria, nicotinealcohol intoxication, arterio-sclerosis concerned the other 12 cases.

Scheerer has found 3 cases of sinus troubles and 134 cases of multiple sclerosis, from a total of 203 cases. Wilmer among 5058 patients seen at the Wilmer Institute has found 30 cases of retrobulbar neuritis of which 12 per cent. were due to multiple sclerosis, 11 per cent. to sinus troubles, 11 per cent. to gall biadder troubles, 6 per cent. to diabetes, 14 per cent. to focal infections (teeth, tonsils, etc.), 16 per cent. Leber's disease, and the rest with a positive tuberculin test.

These great differences in respect to multiple sclerosis could be explained, I believe, considering the irregular frequency of incidence of this disease in different places. In Roumania it is, for instance, met with quite frequently in Cluj and only rarely in Moldavia. Optic retrobulbar neuritis due to this cause remains consequently an exceptional eventuality in 'Jassy.

In what concerns retrobulbar neuritis due to nicotine-alcohol intoxication, I have not seen so far any case, perhaps because smoking in this part of the country remains only moderate and the pipe is practically never used. Further, natural alcoholic beverages are always preferred to the more toxic artificial ones.

From our 10 cases of retrobulbar neuritis 2 were associated with serous meningitis. I have not found this association mentioned 
before, although Popek and Wilmer recommend an examination of the spinal fluid in all cases of retrobulbar neuritis, especially as a means of discovering multiple sclerosis. I shall return to this fact later.

1st Observation.-Profira P., a female, aged 23 years, from Secueni district of Bacau; entered the clinics on March 13, 1934. Has had 12 children, 6 died very young. Suffered with malaria in her childhood, with typhus at the age of 16 and last year with cystitis.

History.-For the last 6 weeks she has a severe headache, especially with frontal localisation and bilateral retro-orbital pains, which are increased by the motion of the eyes. At the same time the sight has quickly diminished, falling in 4 days to nil. She remained blind for 15 days. A physician prescribed glasses at this time. Shortly afterwards the sight began to return, but seeing that no further amelioration followed she decided to come to our clinics.

Present State.-Vision : right, counts fingers at $20 \mathrm{cms}$; left, counts fingers at $40 \mathrm{cms}$. Pupils are equal $(3.5 \mathrm{~mm}$.), reacting weakly to light. The visual field of the right eye cannot be explored. The central vision for colours is lost. The visual field of the left eye attains for white $40-60^{\circ}$ and shows a scotoma of $10^{\circ}$. The achromatopsy is total. On ophthalmoscopic examination the optic disc shows sharp borders and is decolorised in its temporal half. The retinal vessels are normal.

General State.-Complains of a general moderate cephalalgia. The skin and the mucous membranes are pale. The Wassermann reaction is positive. Nothing else to be pointed out. Lumbar puncture : tension (seated) measured with the apparatus of Claude $40 \mathrm{cms}$., falling to 35 after extraction of 10 c.c. Albumin $0.3 \mathrm{v}$; globulins absent : lymphocytes $2, \mathrm{~B}$. Wassermann reaction positive. The patient was treated with bismuth, protein-therapy (milk) and intravenous injections of urotropin. On March 6 the sight showed an improvement. V. R. " counts the fingers at $2.5 \mathrm{~m}$.," V. L. "counts fingers at $4 \mathrm{~m}$."-The visual field : right attains $30-50^{\circ}$ for white and blue with central scotoma, left normal for red, reduced only to the internal half for blue. The left eye scotoma is unchanged.

On March 18, V.R.:=1/6. V.L. $=1 / 4$. On March 20, repeated lumbar puncture : Liquor tension (lying) $35 \mathrm{cms}$., falls to 25 after extraction of 10 c.c Albumin 0.3 , lymphocytes 6 . The patient left the clinics on April 23. She returned on May 2, with V.R.= $1 / 4$, V.L. $=1 / 3$. The peripheral visual fields nearly normal for all colours, only the central scotoma persists. Continues the 
treatment with bismuth and strychnine. Left the clinics again May 23 with vision both eyes $1 / 2$. Re-examined June 2-has V.R. $=1$, V.L. $=2 / 3$. Visual fields for white and colours normal, central scotoma vanished.

2nd Observation.-Ioan S., a male, aged 19 years. Entered the clinics on January 4, 1933. His parents are in good health. Has no brother or sister. In childhood suffered with scarlet fever. In 1929 complained of dizziness and was treated with iron preparations. Admits a certain degree of tobacco and alcohol excess. Since 4 month the sight has been blurred. The troubles have been progressive and during the last month a severe headache has appeared.

Present State.-Vision : right, counts fingers at $60 \mathrm{cms}$.; left, counts fingers at $1 \mathrm{~m}$. Pupillary reflexes are normal. Tension, $20 \mathrm{~mm}$. Visual fields (both eyes), normal for white and for blue, absent for red and green. Both fields show central scotomata. The right one is more extended $\left(10^{\circ}\right)$. Presents the sign of Weekers, can draw both scotomata on paper, the limits of the left look larger than those of the right. At ophthalmoscopic examination nothing particular to point out. Sinuses, bones and teeth are normal. Rotulian reflexes slightly exaggerated. Looks weak and pale. A radioscopic examination of the lungs shows a certain obscuration of both apices and cicatricial lesions in the right hilus.

The $\mathrm{B}$. Wassermann reaction is negative even after reactivation. Mantoux tuberculin test is positive. Blood count is normal. Liquor tension (seated) 52 , falling to 40 after extraction of 10 c.c. Ayala's index under 7.8. The liquor is clear, albumin $0 \cdot 26$, globulins absent, lymphocytes 8 .

Treatment.-Strychnine injections. Protein-therapy (milk 4 in jections of 5-10 c.c. each). Beginning on January 29 received urotropin per mouth and arrhenal injections.

On January 31 , Vision : right, $1 / 10$; left, counts fingers at $4 \mathrm{~m}$. On ophthalmoscopic examination the temporal half of the right optic disc appears discolorised, edged with irregular, interrupted pigmentary deposits. Same visual fields as on admission. Was given a further series of arrhenal injections. Left the clinics on March 10 with V.R.=1/8 V.L.=1/10. Both optic discs remain decolorised in their temporal halves.

Re-entered the clinics again on June 20, 1933, and remained until September. On admission has vision: right, counts fingers at $3 \mathrm{~m}$.; left, counts fingers at $2 \mathrm{~m}$. Central scotomata easily delimitated with the perimeter and with the scotometer, exceeding $10^{\circ}$. With Weekers' method they seem less extended. Peripheral visual fields nearly normal for white, blue and red, 
reduced for green. During the $\mathbf{7 0}$ days which followed we have practised 5 lumbar punctures. The tension of the fluid has varied (seated) between 50 and $80 \mathrm{cms}$. (penultimate puncture). The last examination gave only 25 . The punctures were in general well supported and gave a certain feeling of amelioration. Besides the punctures he received intravenous injections with urotropin, protien-therapy with "lactotal" and strychnine. After the first injections the vision increased $1 / 10$. When leaving (September 1) the vision was : right, counts fingers at $3 \mathrm{~m}$.; left, counts fingers at $2 \mathrm{~m}$.

Again re-examined on February 28, 1934. Had vision : right $1 / 8$, left $1 / 6$. Small paracentral binasal scotomata larger in the left eye $(0-10)$ than in the right $\left(5-10^{\circ}\right)$. Peripheral visual fields nearly normal. The temporal halves of the optic discs decolorised. Liquor tension (lying) $25 \mathrm{cms}$, , falling to 13 after extraction. Ayala's index 4.16. Lymphocytes 3. Nonne-Appelt, negative. Albumin, 020.

\section{Summary}

The first observation is that of a woman, aged 23 years, who lost her sight in 4 days, following marked orbital and ocular pains. The blindness persisted 15 days and receded somewhat at the moment of the admission, when the vision was : right, counts fingers at $20 \mathrm{cms}$.; left, counts fingers at $40 \mathrm{cms}$. There was a central scotomata, a decolorisation of the nasal halves of the optic discs, positive B. Wassermann reaction in blood, and a slight rachidian hypertension. The spinal fluid was normal except for a positive Wassermann reaction. Following protein-therapy and specific therapy the sight was gradually restored, reaching after 4 months $2 / 3$ and 1 with disappearance of the central scotomata. The spinal fluid showed only 6 lymphocytes. The punctures were always well supported.

The second observation concerned an optic retrobulbar neuritis in a boy aged 19 years. He admitted a certain excess of use of tobacco and alcohol. At the beginning the trouble gave no ophthalmoscopic signs. From January 4, 1933, to February 28, 1934, 7 lumbar punctures were practised. The lumbar tension (seated) varied between $50-80 \mathrm{cms}$., except finally when it reached only 25. Chemical and cytologic examination did not point out any abnormality. The punctures were always well supported, even bringing some relief. The vision on admission was : Right, counting fingers at $60 \mathrm{cms}$.; left, counting fingers at $1 \mathrm{~m}$. It improved at the last examination to $1 / 8$ right and $1 / 6$ left. The visual field for red and green was restored and the central scotomata much reduced. 
In both cases, a headache, particularly with frontal localisation, preceded and accompanied the visual troubles. The general and ocular phenomena were ameliorated through repeated punctures.

In these cases the clinical symptoms, central scotomata accompanied by modifications of the peripheral fields, suggest us to range them among the atypical forms which, according to Weil, are due to sinus affections or to affections of the sella turcica.

The American school especially emphasises the importance of the examination of the spinal fluid in order to differentiate the multiple sclerosis, in which one finds a colloido-serologic dissociation : colloidal reaction intensely positive, with $B$. Wassermann, albumin, ${ }^{1}$ pleocytose negative. In our cases the colloidal reactions were not done but a positive Wassermann reaction in the first case and the high liquor tension in the second eliminate the possibility of multiple sclerosis. A positive Ayala sign in both cases is also in favour of a serous meningitis. The hypertension of the spinal fluid without albumin or globulin augmentation (Claude and Oppenheim) eliminates the presence of an intracranial tumour. In serous meningitis the spinal fluid remains nearly unchanged. Another important characteristic of the serous meningitis is the fact that the spinal puncture does no harm, on the contrary has a favourable influence on the general and local symptoms. Therefore the punctures have a real therapeutic importance and in both our cases the amelioration of the visual troubles progressed correspondingly to the normalisation of the spinal pressure.

Another sign of serous meningitis is its long duration, its variable evolution, such as in our second case, which could be followed during one year. In the first case the antiluetic treatment had a rapid efficacy.

In recent publications on retrobulbar neuritis such as arebesides those already recalled-those of Manès, Focosi, Schupfer, numerous aetiologic agents are reviewed, but serous meningitis is not considered. On the other hand the authors point out during the serous meningitis only to papillary stasis (Di Marzio, Claude, Terrien, Renard, Dollfus, Sabadini).

Serous meningitis can show an acute beginning (as in our first case) and then continue a chronic course, or inversely can begin with chronic manifestations and show acute exacerbations (Quinke). It can remain limited to the ventricles (internal, ventricular, or chorioependymitis serosa) or can touch the external membranes (arachnoiditis of Ayala) or produce a cystic arachnoiditis (Claude). The augmentation of the spinal fluid, which determines the symptoms of meningitis serosa might be due to an inflammation of the brain, of the ependyma or of the meninges. Such inflammation can be produced by cranial trauma, a neighbouring lesion 
(otitis, mastoiditis, sinusitis, especially the frontal), a focal infection (teeth, tonsils, etc.), a general infection with typhoid bacilli, influenza, pneumococci, syphylis, tuberculosis, and certain intoxications (uraemia, lead, lactation).

Nevertheless we can find sometimes cases (such as our second) in which no precise aetiology can be discovered. I believe we cannot exclude the possibility of meningeal infections with certain unknown agents, ultra-viruses, etc.

The practical conclusions of our observations remain then, that in cases of retrobulbar neuritis we should think also of serous meningitis and practice a lumbar puncture, which besides its diagnostic value will have a good therapeutic effect and will have a favourable result not only on the general cerebral symptoms but also on the ocular manifestations.

\section{BIBLIOGRAPHY}

1. Herzog.-Ueber die Neuritis retrobulb. Arch. f. Augenheilk., Vol. XCIX, p. 291, 1928. An. in Zentralbl.f. d.g. Ophthal. ,Vol. XX, p. 752, 1929.

2. Scheerer, Richard.-Ueber die Ursachen der Neuritis retrob. Klin. Monatsbl. f. Augenheilk., Vol. LXXXIII, p. 164, 1928.

3. Wilmer.-Chronic retrobulb. neuritis. Jl. Tenn. State Med. Ass., 1930. An. in Amer. Jl. of Ophthal., p. 469, 1931.

4. Popek.-Les examens du liquide céph-rah. dans les nèurites retrobulb. Soc. d'ophtal. Tchékslovaque 7ème congrès, 1932. An. in Ann. d'ophtal., p. 607, 1933.

5. Weekers.-Un nouveau signe clinique pour le diagnostic differentiel et le pronostic des néurites rétrobulbaires. Arch. d'ophtal., p. 485, 1932.

6. Di Marzio - Die Augensymptome bei der Meningitis serosa. Zentralbl.f.d. g. Ophthal., p. 13, 1934.

7. Weill.-Saggio di classific. delle neuriti retrob. Soc. Ital oto-neuro-ophtal. Congrès, Bologna, 1932. An. in Zentralbl.f.d.g. Ophthal., Vol. XXXI, p. $651,1934$.

8. Manès.-Die Neuritis retrob. Ihre diagnostische Wichtigkeit. Neue etiologische Gesichtspunkte Gesichtsfeldmessungen. Serv. de opht. Hsp. Rawson y Aleman Buenos Aires Semana Med., 1933. An. in Zentralbl. f.d.g. Ophthal., p. 667, 1934.

9. Schupfer.-Sulla neurite retrob. acuta con perticolare riguardo al probl. etiopatogenico e diagnostico. Boll. d'ocul., p. 1143, 1936.

10. Terrien, Renard, et Dollfus.-Stase papillaire et épendimite séreuse. Arch. d'ophtal., p. 288, 1928.

11. Sabbadini.-Rezidivirende seröse Meningitis und ihre Augensymptome Rev. otal. 1930. An. in Zentralbl. f. d. g. Ophthal., July, 1935.

12. Terrien.-Valeur semeiologique de la stase papillaire dans les meningites séreuses. Arch. d'ophtal.. July, 1935. 